\title{
UN ESTUDIO DE LA IRONÍA EN EL CAPÍTULO 9 DEL QUIJOTE DE 1605
}

ACERCA DE LA DEFINICIÓN DE “IRONía”y SU IMPORTANCIA EN EL QUUJOTE

Comúnmente se afirma que la ironía es la "figura retórica que consiste en dar a entender lo contrario de lo que se dice" 1 . Esta es quizá la concepción más aceptada o difundida. Sin embargo, basta analizar algunos ejemplos de enunciados que en general se considerarían irónicos para darse cuenta de que esa definición es bastante estrecha. Dice el narrador inicial del Quijote, aquél que no quería acordarse del lugar de la Mancha donde a Alonso Quijano se le secaba el cerebro de a poco:

[1] Y puesto que aunque los conocía no los sabía leer, anduve mirando si parecía por allí algún morisco aljamiado que los leyese, y no fue muy dificultoso hallar intérprete semejante, pues aunque le buscara de otra mejor y más antigua lengua le hallara ${ }^{2}$.

Aquí, el narrador no quiere decir que a él le fue difícil encontrar un traductor de árabe; quiere decir que en ese lugar (el Alcaná de Toledo) había muchos árabes y judíos: estos últimos son

${ }^{1}$ Real Academia Española, Diccionario de la Lengua Española, Espasa Calpe, Madrid, 1992, p. 1189. Definiciones análogas aparecen en otros diccionarios y manuales: "La ironía consiste en decir algo de manera tal que se entienda o se continúe de forma distinta a la que las palabras primeras parecen indicar" (Angelo Marchese y JoAQuín ForRadellas, Diccionario de retórica, crítica y terminología literaria, Ariel, Barcelona, 1991, s.v.; las cursivas son mías).

${ }^{2}$ Miguel de Cervantes, El ingenioso hidalgo don Quijote de la Mancha, ed., introd. y notas M. de Riquer, Planeta, Buenos Aires, 1999, I, cap. 9, p. 102. Cito por esta edición. 
los hablantes de "otra mejor y más antigua" lengua. Puede in terpretarse que el enunciado es irónico porque desvaloriza el lugar donde se encuentran los manuscritos sobre la vida de don Quijote; su intención es desacreditar el origen del historiador Cide Hamete Benengeli. Algo similar ocurre en el siguiente pasaje:

[2] Esta Dulcinea del Toboso, tantas veces en la historia referida, dicen que tuvo la mejor mano para salar puercos que otra mujer de toda la Mancha (Quijote, I, cap. 9, p. 102).

Los manuscritos árabes que lee el moro aljamiado no quieren decir que Dulcinea fuera mala salando chanchos; pero tampoco quieren decir que Dulcinea fuera una dama delicada. La intención es poner en evidencia que la imagen de dama angelical y frágil que tiene don Quijote se contradice duramente con la "verdadera" Dulcinea/Aldonza Lorenzo?.

${ }^{3}$ La visión "realista" de la aldeana rústica es la que tiene Sancho Panza, quien se acuerda de la hija de Lorenzo Corchuelo y Aldonza Nogales. Don Quijote exalta la recatada educación que éstos le han brindado a Dulcinea y el escudero se acuerda de esa mujer: "Bien la conozco-dijo Sancho-, y sé decir que tira tan bien de una barra como el más forzudo zagal de todo el pueblo. ¡Vive el Dador, que es moza de chapa, hecha y derecha y de pelo en pecho, y que puede sacar la barba del lodo a cualquier caballero andante, o por andar, que la tuviere por señora! ¡Oh hideputa, qué rajo que tiene, y qué voz! Sé decir que se puso un día encima del campanario del aldea a llamar a unos zagales suyos que andaban en un barbecho de su padre, y aunque estaban allí más de media legua, así la oyeron como si estuvieran al pie de la torre. Y lo mejor que tiene es que no es nada melindrosa, porque tiene mucho de cortesana: con todos se burla y de todo hace mueca y donaire" (Quijo$t e, \mathrm{I}$, cap. 25, p. 262). El fragmento es complejamente irónico. El narrador es el responsable de la ironía, no el personaje. Sancho es literal; desde su visión de aldeano simple elogia lo que cree son las virtudes de una mujer de su misma condición social. Pero el narrador irónico no da a entender lo contrario de lo que dice Sancho. La ironía surge, nuevamente, del rudo contraste entre la visión idealizada de don Quijote y la cuasi-masculinidad de la Dulcinea descrita por el escudero. Los enunciados de Sancho son irónicos porque por medio de ellos el narrador hace burla de los elogios de don Quijote y de su visión distorsionada del mundo en el que le toca vivir. Creo que esta forma particular de ironía, donde la fuente no es el personaje, también se da al final de Lazarillo de Tormes, cuando Lázaro dice estar "en la cumbre de toda buena fortuna" (La vida de Lazarillo de Tomes y de sus fortunas y adversidades, Kapelusz, Buenos Aires, 1967, tratado VII, p. 127). Los lectores captamos la ironía del enunciado sin que sea Lázaro el que quiera dar a entender su condición de marido engañado y hombre oprimido. De todas maneras, la ironía del final del Lazarillo manifiesta una complicación especial porque el personaje-que 
En síntesis, ejemplos como [1] y [2] nos muestran que la definición tradicional de la ironía resulta, en principio, poco operativa: un enunciado no necesariamente es irónico porque -como afirman los diccionarios o los manuales de retórica- "da a entender lo contrario de lo que dice". Ahora bien, lo que coincidimos en denominar ironía parece uno de los recursos fundamentales del Quijote. Por caso, el célebre y polémico Harold Bloom da a la ironía un valor primordial en la obra de Cervantes:

Aunque Cervantes siempre se muestra cauteloso a la hora de aparecer como un buen católico, no leemos Don Quijote como si fuera una obra devota. Es de presumir que Cervantes fue cristiano viejo, no descendiente de judíos conversos ni nuevos cristianos, aunque tampoco podemos estar seguros de sus orígenes, al igual que no podemos conjeturarcon precisión cuáles eran sus opiniones. Caracterizar sus ironias es una tarea imposible; pasarlas por alto también es imposible ${ }^{4}$.

La sentencia final de Bloom es al mismo tiempo un freno y un estímulo con el que pueden coincidir los devotos, de Cervantes. Entender algunos de los aspectos del uso de la ironía permitirá explicar por qué el Quijote nos hace reír, y también por qué nos confunde. Del mismo modo, la comprensión de las ironías quijotescas servirá para definir este recurso, que obviamente trasciende la literatura y forma parte, junto con los otros recursos expresivos, de la "comunicación ordinaria"s.

En este trabajo intentaré poner a prueba, en el caso del Quijote, la definición de ironía que se ofrece en el marco de la teoría de la relevancia de Dan Sperber y Deirdre Wilson ${ }^{6}$. Básicamente, estos autores sostienen que la ironía es un enunciado de carácter polifónico que desaprueba el significado literal de otro

no es la fuente de la ironía- es también el narrador. Tal vez por ello resulte posible, en este caso, la hipótesis de la "ironía del autor".

${ }^{4}$ El canon occidental, Anagrama, Barcelona, 1994, p. 140; las cursivas son mías.

5 Como decía Roman Jakobson, la "función poética" del lenguaje está presente en los usos no literarios del lenguaje, así como en la literatura aparecen las demás funciones. La ironía podría incluirse en ese vasto conjunto de recursos que contribuyen a la "poeticidad" o "literariedad", pero de ningún modo puede excluírsela del "uso ordinario" o "no artístico" del lenguaje ("Lingüística y poética", Ensayos de lingüistica general, Planeta-Agostini, Madrid, 1986).

${ }^{6}$ Dan Sperber \& Deirdre Wilson, Relevance. Communicalion and cognition, Blackwell, Oxford-Cambridge, 1995. 
enunciado. A partir de esta idea voy a analizar el capítulo 9 de la primera parte del Quijote. El capítulo es notable no sólo porque el primer narrador presenta al "sabio" "galgo" Cide Hamete Benengeli, sino también porque constituye un magnífico ejem plo del uso reiterado de lo que se suele llamar ironía. En definitiva, el estudio de los enunciados irónicos en este pasaje de la obra de Cervantes nos permitirá advertir que la ironía no es una figura cuyo significado consiste en el simple reverso de lo que se ha hecho explícito.

\section{UN ANÁLISIS PRAGMALINGÜÍSTICO DE LA IRONÍA}

Voy a tratar de manejar entonces la definición de ironía propuesta en el marco de la teoría pragmalingüística de la relevancia. Esta teoría es resultado del trabajo conjunto del francés Dan Sperber y de la inglesa Deirdre Wilson y uno de sus objetivos principales es presentar un modelo teórico que explique la comunicación humana. Ellos suponen un principio universal, la relevancia, que rige toda interacción comunicativa. Ese principio se sostiene en la ostensión (el hecho de hacer manifiesta alguna cosa) y en la inferencia (los procesos cognitivos o mentales). Otro supuesto fundamental es que estos procesos tienen como finalidad la obtención del mayor efecto cognitivo en relación con el menor esfuerzo de procesamiento. De manera general, el principio de la relevancia expresa que todo enunciado presupone su relevancia: todo enunciado lleva consigo el presupuesto de que es el más apropiado que el hablante pudo haber producido y lleva también la garantía de que su procesamiento permitirá al oyente un beneficio informativo. Los conceptos relevancia y relevante significan pertinencia ${ }^{7}$. Para Sperber y Wilson un enunciado es relevante porque transmite información nueva que se vincula de alguna manera con la información que posee el hablante y además comunica la intención de informar. Ese proceso ostensivo-inferencial hace posible que el oyente incre-

${ }^{7}$ Los conceptos relevantey relevancia son anglicismos que se han impuesto en la bibliografía. De todas formas, la palabra "pertinente" no sólo parece más genuinamente castellana sino que además sugiere que algo es digno de ser procesado porque "viene al caso" o porque "tiene que ver" con lo que se dijo o con lo que se conoce. La información que manifiesta el hablante se relaciona con la información vieja que posee el oyente para que el oyente obtenga una conclusión que enriquecerá su propio "entorno cognitivo". 
mente su conocimiento del mundo y que suponga que vale la pena tratar de entender lo que los otros le dicen. No parece exagerado afirmar que, así como Chomsky propone una explicación de la gramática universal, Sperber y Wilson sugieran la hipótesis de una pragmática universal ${ }^{8}$.

En el contexto de la teoría de la relevancia, la definición tradicional de ironía ("expresión donde se quiere decir lo contrario de lo que se dice") no resulta satisfactoria porque presenta dos limitaciones cruciales:

(1) permite incluir emisiones absurdas;

(2) deja de lado ejemplos de enunciados que se consideran irónicos, pero en los que no se da a entender lo contrario de lo que se dice, como [1] y [2].

Entonces, Sperber y Wilson plantean que la ironía es un caso de enunciado de eco que desaprueba el enunciado que reproduce $^{9}$. (La relevancia se obtiene porque el enunciado irónico genera más implicaciones que las que generaría un enunciado "literal".) La idea de que la ironía es un enunciado de carácter desaprobatorio permite establecer una relación directa con la escritura de Cervantes. En efecto, la ironía no puede definirse como aquella expresión donde se quiere decir lo contrario de lo que se dice. Por ejemplo, si afirmo en este momento:

\section{[3] Este artículo desaparecerá}

para querer decir que el artículo está bien grabado o bien impreso y que por ello no desaparecerá, entonces estoy dando un ejemplo que satisface la definición tradicional de ironía (¡quise dar a entender lo contrario de lo que dije!). Pero en ese caso el ejemplo [3] presentaría un absurdo, un absurdo que nos ayuda

${ }^{8}$ Para Chomsky, la Gramática Universal es la facultad del lenguaje en su estado inicial. Sperber y Wilson admiten que el mejor modelo gramatical es el generativista, pero reconocen que una teoría formal no puede dar cuenta de cómo las oraciones se pueden usar para la comunicación de un número indefinido de pensamientos. La teoría de la relevancia continúa el trabajo comenzado por la teoría generativa, cuyo límite es la caracterización formal de la gramática. Los dos programas de investigación se basan en procesos cognitivos que quizá puedan entenderse como complementarios: gramática universal y pragmática universal.

${ }^{9}$ Sperber y Wilson, op. cit., p. 241. 
a entender que la ironía tiene que definirse en otros términos. Así, Sperber y Wilson sugieren que la ironía es un enunciado de eco que desaprueba el enunciado que reproduce. Eso ocurre con los enunciados de los ejemplos [4] y [5b], que desaprueban ostensiblemente enunciados ajenos:

[4] Cándido, temblando como un filósofo, se escondió lo mejor que pudo durante la matanza heroica. Al fin, mientras los dos reyes hacían entonar un Tedeum para celebrar la victoria en cada campo, decidió irse a razonar... ${ }^{10}$.

[5] (a) Argentina jugó bien en el último mundial.

(b) Sí, jugó fantásticamente bien ${ }^{11}$.

El ejemplo [4] es irónico por varias razones. Voltaire no quiere decir que los dos reyes que celebraban las victorias ganaron, $o$ que ambos perdieron, sino que desaprueba el fervor fanático y triunfalista que causa la guerra. Tampoco quiere decir que Cándido no temblara o que no se fuera a reflexionar, sino que desaprueba la cobardía y la falta de sentido práctico de muchos intelectuales. Algo similar ocurre con [5b], enunciado explícitamente ecoico mediante el cual el hablante desacredita la opinión de su interlocutor: quiere decir que la selección argentina ha jugado mal. Los dos ejemplos consisten en casos de ironía no porque se dé a entender lo contrario de lo que se dice (cosa que ocurre en el ejemplo [5b] pero no en [4]); los ejemplos tienen en común que desaprueban de forma manifiesta un enunciado ajeno. El enunciado desaprobado puede aparecer en el contexto del intercambio, como en [5], o puede "reconstruirse", como en [4]. Voltaire es arque típico en este sentido: sus ironías nos desafían a inferir cuál es el enunciado que se desaprueba.

En el marco de la teoría de la relevancia se destaca que concebir la ironía como "un enunciado polifónico de carácter desaprobatorio" produjo un importante cambio de enfoque en el estudio pragmalingüístico de los recursos retóricos ${ }^{12}$. Una pre-

${ }^{10}$ Francois Arouet de Volta ire, Cándido o el optimismo, pról. y cronología de F. Alonso, EDAF, Madrid, 1999, III, p. 38.

${ }^{11}$ Para una adecuada interpretación de la ironía del ejemplo [5] tal vez deba recordarse que la selección argentina de futbol no pasó la primera ronda del Mundial 2002.

12 En una publicación de 1998, R. Carston y S. Uchida promueven un debate sobre la definición de ironía. Varios autores discuten con Sperber y 
gunta crucial para la teoría de la relevancia es si todo enunciado irónico supone una desaprobación abierta. En este sentido, también podemos preguntarnos si la ironía es necesariamente agresiva y si puede diferenciársela de lo que llamamos "sarcasmo". En algunos casos de ironía, la fuente reproducida y desaprobada (por ejemplo, la fuente de la cual el enunciado se hace eco) es vaga, como en el ejemplo [4]; en otros, muy precisa y aun explícita, como en [5]. Sin embargo, parece que la ironía no siempre es desafiante. En ciertos casos puede ser amistosa, tal vez si el hablante y el oyente no mantienen una relación social distante, como en el ejemplo [6]:

[6] En un día de viento, Juan, después de ver a su amiga María con el pelo revuelto le dice: "Estás preciosa con tu nuevo peinado".

Juan ha sido irónico: quiere decir que el peinado es algo gracioso o ridículo, pero no quiere ofender a su amiga. El enunciado reprobado (y del cual Juan se hace eco) es algo así como "Tu peinado es lindo". Para que el enunciado sea irónico y, con ello, ecoico, no es necesario que el enunciado reproducido y aprobado se haya emitido previamente al estilo del ejemplo [5]. La ironía suele crear, como una implicatura ${ }^{13}$, el enunciado del que se hace eco y al que desaprueba.

A veces, la ironía presenta una (aparente) disociación entre la opinión reproduciday el estado de cosas manifiesto, como en [7]:

[7] El profesor entra al aula y ve que se encuentra terriblemente desordenada; entonces dice: "Me encantan los chicos que mantienen el aula en orden”.

Wilson y aventuran las siguientes hipótesis. Según K. I. Seto hay enunciados irónicos no ecoicos; para los editores citados se dan casos muy difíciles que exigen una clarificación; $M$. A. Yamanashi entiende que falta considerar ciertos tropos asociados directamente con la ironía. Véase el libro de R. CARSTON y S. UCHIDA (eds.), Relevance theory. Applications and implications, J. Benjamins, Amsterdam-Philadelphia, 1998.

${ }^{13}$ Una implicatura conversacional es, en términos de la conocida propuesta de H. P. Grice (de 1975), una inferencia que elabora el oyente a partir de la violación ostensible de una máxima comunicativa; se trata de un caso de explotación del principio cooperativo. El hablante $\mathrm{H}$ dice $p$ pero hace manifiesto al oyente que quiere decir q ("Lógica y conversación", en $L a$ búsqueda del significado, ed. L. M. Valdés Villanueva, Tecnos, Madrid, 1991, pp. 511-530). 
En ciertos casos, que para Sperber y Wilson son bastante $\operatorname{marcados}^{14}$, la ironía desaprueba un enunciado negativo. Como "menos por menos" da más, la ironía es "apreciativa". Eso ocurre en el ejemplo [8]:

[8] El profesor, que sabe que María es una alumna responsable y prolija, le devuelve a María el trabajo aprobado con un diez y le dice: "Tu trabajo está tan mal como siempre".

Vale una aclaración. En los ejemplos [5]-[8] el hablante sí implica "lo contrario" de lo que dice. De todas formas, ya vimos que ésa no es una definición que pueda abarcar todos los casos, como los fragmentos [1] y [2] del Quijote citados al comienzo.

Tal vez los diversos ejemplos tratados permiten identificar lo que se llama "sarcasmo" como un tipo particular de ironía. Efectivamente, el sarcasmo sería un tipo de ironía que desaprueba fuertemente un supuesto que el oyente valora. Consideremos el ejemplo [9]:

[9] El profesor, que sabe que Juan es un alumno cuyos trabajos no han sido buenos, le devuelve a Juan el trabajo reprobado con un dos y le dice: "Tu trabajo es un formidable aporte para la lingüística moderna".

En el ejemplo [9] el hablante es sarcástico porque el profesor invade la "imagen positiva" de su alumno" ${ }^{15}$. La pregunta que nos hicimos antes acerca de si la ironía es agresiva podría responderse de este modo: en realidad, no lo es; en algunos casos puede llegar a funcionar de manera apreciativa. Reservemos el concepto de "sarcasmo" para aquellos casos en los cuales sí se ofende la imagen del destinatario, como en el descortés ejemplo [9].

14 "Irony and relevance: A reply to Seto, Hamamoto and Yamanashi", en R. Carston y S. Uchida, op. cit., pp. 283-294.

${ }^{15}$ Puede plantearse la siguiente hipótesis para distinguir ironía de sarcasmo: un enunciado es sarcástico si ataca la imagen positiva del oyente, es irónico si sólo amenaza dicha imagen. Según la teoría de la cortesía verbal, todos los adultos competentes de una comunidad tenemos una imagen, que se desdobla en dos instancias. La imagen positiva consiste en el deseo de que los demás valoren lo que nosotros valoramos; la imagen negativa es el deseo de que los demás no nos impongan lo que debemos hacer (Penelope Brown \& STEPHen Levinson, Some universals in language usage, prol. J. Gumperz, Cambridge University Press, Cambridge, 1987). 
En ocasiones, la ironía permite que el hablante busque atenuar la desaprobación de un supuesto ajeno; de esta manera el hablante genera un efecto más o menos humorístico que disminuye la amenaza de la imagen positiva del oyente. Así, por medio del viejo recurso del chiste, el hablante indica a su interlocutor que lo considera cercano o directamente un par ${ }^{16}$. En el ejemplo [10] el profesor es amigable con su alumno precisamente de esta forma:

[10] El profesor, que le entregaa Pedroun examen desaprobado,le dice: "Tu trabajo tiene algunas fallas que se pueden corregir".

En síntesis, los diez ejemplos analizados hasta aquí permiten que aceptemos la siguiente definición: "la ironía es el recurso mediante el cual un enunciado desaprueba el significado literal de otro enunciado". Después de estas últimas consideraciones sobre ejemplos artificiales -método muy propio de la teoría de la relevancia- volveré a los más interesantes enunciados irónicos del capítulo en el que aparece el insigne Cide Hamete Benengeli.

\section{ENUNCIADOS IRÓNICOS DEL CAPÍTULO 9}

El capítulo 9 es globalmente irónico porque en él sabemos que la "verdadera" historia es la traducción de un relato del sabio Cide Hamete Benengeli. Una de las mayores ironías es que el narrador inicial destaca que el sabio que escribió la historia de don Quijote pertenece a una estirpe de mentirosos:

[11] Si a ésta se le puede poner alguna objeción cerca de su verdad, no podrá ser otra sino haber sido su historiador arábigo, siendo muy propio de los de aquella nación ser mentirosos; aunque, por ser tan nuestros enemigos, antes se puede entender haber quedado falto en ella que demasiado (Quijote, I, cap. 9, p. 103).

${ }^{16} \mathrm{El}$ chiste es una típica estrategia de cortesía positiva, al igual que las fórmulas de tratamiento amistosas, las "malas palabras" o los diminutivos, por ejemplo. Por medio de estos recursos el hablante da a entender al oyente que ambos se mueven en un terreno común y que la distancia entre emisor y receptor es mínima o inexistente. 
Paraijustificar que el capítulo es "globalmente" irónico pueden considerarse las oraciones del texto y ver en cuáles de ellas se expresan enunciados irónicos. El capítulo 9 consta de 85 oraciones y 113 cláusulas subordinadas (incluyendo las de verbos conjugados y no conjugados) ${ }^{17}$. Al menos unas 34 de las 85 oraciones sirven como realización de enunciados irónicos. La "alta proporción” de ironías resulta más notable cuando se tiene en cuenta que los enunciados carentes de fuerza irónica son los que narran sucesos puntuales de la batalla entre don Quijote y el vizcaíno. En este apartado se efectúa el reconocimiento y la catalogación de las ironías del capítulo 9, que han sido agrupadas en cuatro temas fundamentales:

(1) la pelea entre don Quijote y el vizcaíno,

(2) los elogios retóricos,

(3) la documentación histórica,

(4) Dulcinea.

Para entender las ironías de estos cuatro temas desde un enfoque pragmalingüístico es necesario recurrir al concepto de "cancelación" y al ya visto de "enunciado desaprobado". Las implicaturas conversacionales son cancelables del mismo modo que la conclusión de un razonamiento inductivo: puede anularse mediante la simple introducción de un enunciado adicional. Por ejemplo, la conclusión que establece "Todos los cisnes son blancos" sobre la base de que todos los cisnes conocidos son blancos se cancela en el momento que alguien puedaijustificar empíricamente el enunciado "Vi un cisne negro"18. Más arriba he dicho que el enunciado reprobado de una ironía puede aparecer como una implicatura; la ironía misma -lo que el hablante

${ }^{17}$ El método de segmentación de oraciones es estrictamente gramatical. Se ha dividido el texto en oraciones y cláusulas subordinadas. Por su extensión y carácter preparatorio, esa segmentación no se incluye en el cuerpo principal del trabajo. (Puede consultarse el documento en el Apéndice, "División en oraciones y proposiciones subordinadas").

${ }^{18} \mathrm{La}$ conclusión de un razonamiento inductivo es cancelable; pero la conclusión de uno deductivo no lo es. A diferencia de la implicatura conversacional, la presuposición no es cancelable. En efecto, la presuposición se mantiene con la negación de la proposición en la que aparece: para tener valor de verdad, tanto la proposición "El rey de Francia es pelado", como su negación "El rey de Francia no es pelado", presuponen "El rey de Francia existe" (Peter F. Strawson, Introducción a una teoría de la lógica, Nova, Buenos Aires, 1969, p. 207). 
quiere decir reprobando un enunciado ajeno- también es una implicatura19. La "cancelación" de una ironía entonces puede ser el enunciado que explicita qué se quiere decir. El efecto de una ironía se anula si se aporta la información implicada: ya no hay ironía sino comunicación explícita. El conocido personaje de dibujos animados, Homero Simpson, es un verdadero experto para cancelar las ironías que él mismo intenta producir:

[12] (Homero está muy enojado con Moe, el dueño del bar, porque éste le ha robado la fórmula de un trago exitoso).

MARge (la mujer de Homero): "Homero, deberías sentirte feliz porque, aunque no ganas dinero, mucha gente es feliz con lo que inventaste".

Homero: “¡Oh, sí! Soy el duendecito mágico que reparte sueños y felicidad. ¿Qué bueno que soy! Laralalá”. (Se va, cierra la puerta y vuelve). "Por cierto, estoy siendo sarcástico"20.

Aquí, Homero cancela el efecto de su ironía al expresar qué quiso decir. En resumen, toda ironía se puede cancelar al explicitar cuál es su efecto. Se cancela porque precisamente ya no vale como ironía. Repitámoslo: su contenido implícito se ha hecho explícito.

También conviene recordar que los enunciados irónicos son ecoicos. Por eso se reconstruye el enunciado (generalmente implícito) que el enunciado irónico está reprobando. Como podrá advertirse, en el el capítulo 9 del Quijote, en muy pocos casos el enunciado reprobado es la negación o lo inverso del enunciado irónico. Cada una de las Tablas que se presenta a continuación analiza los enunciados irónicos correspondientes a los cuatro temas antes mencionados. El método es el siguiente:

1) Se transcribe la oración tal y como figura en el texto de Cervantes, por caso: "haciéndolo ansí, volviendo de improviso el arábigo en castellano, dijo que decía: Historia de don Quijote de la Mancha, escrita por Cide Hamete Benengeli, historiador arábigo" (Quijote, I, cap. 9, p. 102).

${ }^{19}$ Así la trata GRice, op. cit. Para él, los casos de ironía constituyen una violación ostensible de la máxima de calidad: el hablante dice algo que es manifiestamente falso.

${ }^{20}$ El ejemplo está tomado de José M. GIL, Introducción a las teorias lingüústicas del siglo XX, RIL, Santiago de Chile, 2001, p. 219. 
2) Se sugiere una posible cancelación de la implicatura (por ajemplo, se hace explícito el efecto del enunciado irónico). Para el caso trascrito en el párrafo anterior puede ser así: "La historia de don Quijote no tiene como autor un sabio de prestigio sino un árabe (lo que para la creencia general hará que la obra resulte menos confiable)".

3) Por último, se propone cuál es el enunciado reprobado en virtud del cual se genera la ironía. En el ejemplo aquí tratado puede ser éste: "El autor de la historia de don Quijote es un historiador prestigioso".

En la primera columna de la Tabla se indica el número que corresponde a la oración trascrita en la segmentación del capítulo 9 (cf. nota 17 y, eventualmente, el Apéndice, "División en oraciones y proposiciones subordinadas").

TABLA 1

Enunciados irónicos de la pelea entre don Quijote y el vizcaino

\begin{tabular}{llll}
\hline \multicolumn{1}{c}{ Expresión literal } & \multicolumn{1}{c}{ Cancelación } & \multicolumn{1}{c}{ Enunciado reprobado } \\
\hline 1 & Donde se concluye y da & La batalla fue & La batalla fue \\
fin a la estupenda batalla & más bien ridicula. & estupenda. El \\
que el gallardo vizcaíno & Don Quijote no es & vizcaino es gallardo. \\
y el valiente manchego & cobarde, pero está \\
tuvieron. & $\begin{array}{l}\text { Dobredimensionado Qujote tiene } \\
\text { peleas dignas de los } \\
\end{array}$ & $\begin{array}{l}\text { por lo ridículo del } \\
\text { contexto. }\end{array}$ & libros de caballerías.
\end{tabular}

2 Dejjamos en la primera parte desta historia al valeroso vizcaíno y al famoso don Quijote con las espadas altas $y$ desnudas, en guisa de descargar dos furibundos fendientes, tales, que si en lleno se acertaban, por lo menos se dividirían y fenderían de arriba a abajo y abrirían como una granada
Los combatientes están furiosos; lo insólito de la pelea hace que la furia sea desproporcionada. (La ira de un

Don Quijote y el vizcaíno son dos combatientes comparables a los protagonistas de los libros de caballerías. gusano o de un lobo anciano podrían ser causa de risa en las fábulas.) 
TABLA 1 (continuación)

5 Parecióme cosa imposible La historia de y fuera de toda buena costumbre que a tan buen caballero le hubiese faltado algún sabio que tomara a cargo el escrebir sus nunca vistas hazañas, cosa que no faltó a ninguno de los caballeros andantes, de los que dicen las gentes que van a sus aventuras, porque cada uno dellos tenía uno o dos sabios, como de molde, que no solamente escribían sus hechos, sino que pintaban sus más mínimos pensamientos y niñerías, por más escondidas que fuesen;
41 Estaba en el primero cartapacio pintada muy al natural la batalla de don Quijote con el vizcaíno, puestos en la mesma postura que la historia cuenta, levantadas las espadas, el uno cubierto de su rodela, el otro de la almohada, y la mula del vizcaíno tan al vivo, que estaba mostrando ser de alquiler a tiro de ballesta.
Don Quijote es disparatada o ridicula. No pudo haber un sabio prestigioso que se dedicara a estudiar su vida.

El recurso de los sabios omniscientes es un artificio inverosímil o poco eficaz.

La expresión nunca vistas hazañas es ambigua y, por ello, irónica. Que las historias de Don Quijote son nunca vistas es estrictamente verdadero.

El dibujo presenta una descripción de la ridícula pelea entre don Quijote y el vizcaíno.
Don Quijote es un caballero cuya gloria se compara a la de los héroes de las novelas.

Las novelas de caballería son obras verdaderas o verosímiles.

Las aventuras de don Quijote y de los otros caballeros son verdaderas.

Esta combinación de lo literal y lo figurado parece confirmar la idea de Bloom de que nunca sabemos bien qué es lo que Cervantes quiso decir.

El vizcaíno es un caballero gallardo e imponente. 
TABLA 1 (continuación)

\begin{tabular}{|c|c|c|c|}
\hline 44 & $\begin{array}{l}\text { Estaba Rocinante } \\
\text { maravillosamente } \\
\text { pintado, tan largo y } \\
\text { tendido, tan atenuado y } \\
\text { flaco, con tanto espinazo, } \\
\text { tan hético confirmado, } \\
\text { que mostraba bien al } \\
\text { descubierto con cuánta } \\
\text { advertencia y propiedad } \\
\text { se le había puesto el } \\
\text { nombre de Rocinante. }\end{array}$ & $\begin{array}{l}\text { A pesar de que se } \\
\text { cree un caballero } \\
\text { gallardo, don } \\
\text { Quijote monta un } \\
\text { animal de muy mala } \\
\text { apariencia. }\end{array}$ & $\begin{array}{l}\text { Rocinante es } \\
\text { el caballo más } \\
\text { esbelto del mundo } \\
\text { (enunciado de don } \\
\text { Quijote). }\end{array}$ \\
\hline 59 & $\begin{array}{l}\text { Puestas y levantadas } \\
\text { en alto las cortadoras } \\
\text { espadas de los dos } \\
\text { valerosos y enojados } \\
\text { combatientes, no } \\
\text { parecía sino que estaban } \\
\text { amenazando al cielo, a la } \\
\text { tierra y al abismo: }\end{array}$ & $\begin{array}{l}\text { Los combatientes } \\
\text { están furiosos; } \\
\text { pero lo insólito de } \\
\text { la pelea hace que } \\
\text { la furia parezca } \\
\text { desproporcionada. }\end{array}$ & $\begin{array}{l}\text { Don Quijote y } \\
\text { el vizcaíno son } \\
\text { dos caballeros } \\
\text { comparables a los } \\
\text { de los libros de } \\
\text { caballerías. }\end{array}$ \\
\hline 60 & $\begin{array}{l}\text { tal era el denuedo y el } \\
\text { continente que tenían. }\end{array}$ & $\begin{array}{l}\text { Los combatientes } \\
\text { están furiosos; } \\
\text { pero lo insólito de } \\
\text { la pelea hace que } \\
\text { la furia parezca } \\
\text { desproporcionada. }\end{array}$ & $\begin{array}{l}\text { Don Quijote y } \\
\text { el vizcaíno son } \\
\text { dos caballeros } \\
\text { comparables a los } \\
\text { de los libros de } \\
\text { caballerías. }\end{array}$ \\
\hline 62 & $\begin{array}{l}\text { el cual fue dado con tanta } \\
\text { fuerza y tanta furia que, } \\
\text { a no volvérsele la espada } \\
\text { en el camino, aquel solo } \\
\text { golpe fuera bastante } \\
\text { para dar fin a su rigurosa } \\
\text { contienda y a todas las } \\
\text { aventuras de nuestro } \\
\text { caballero; }\end{array}$ & $\begin{array}{l}\text { Los combatientes } \\
\text { están furiosos; } \\
\text { pero lo insólito de } \\
\text { la pelea hace que } \\
\text { la furia parezca } \\
\text { desproporcionada. }\end{array}$ & $\begin{array}{l}\text { Don Quijote y } \\
\text { el vizcaíno son } \\
\text { dos caballeros } \\
\text { comparables a los } \\
\text { de los libros de } \\
\text { caballerías. }\end{array}$ \\
\hline 63 & $\begin{array}{l}\text { mas la buena suerte, que } \\
\text { para mayores cosas le } \\
\text { tenía guardado, torció la } \\
\text { espada de su contrario, }\end{array}$ & $\begin{array}{l}\text { Don Quijote no } \\
\text { puede perder } \\
\text { porque es el } \\
\text { protagonista de una } \\
\text { historia que nos } \\
\text { hará reír. }\end{array}$ & $\begin{array}{l}\text { La historia de don } \\
\text { Quijote es digna de } \\
\text { un relato extenso y } \\
\text { solemne. }\end{array}$ \\
\hline
\end{tabular}


TABLA 1 (conclusión)
64 de modo que, aunque le acertó en el hombro izquierdo, no le hizo otro daño que desarmarle todo aquel lado, llevándole, de camino, gran parte de la celada, con la mitad de la oreja;

66- ¡Váleme Dios, /

67 quién será aquel que buenamente pueda contar ahora la rabia que entró en el corazón de nuestro manchego, viéndose parar de aquella manera!

68 No se diga más sino que fue de manera, que se alzó de nuevo con los estribos, y apretando más la espada en las dos manos, con tal furia descargó sobre el vizcaíno, acertándole de lleno sobre la almohada y sobre la cabeza, que, sin ser parte tan buena defensa, como si cayera sobre él una montaña, comenzó a echar sangre por las narices y por la boca, y por los oídos, y a dar muestras de caer de la mula abajo, de donde cayera, sin duda, si no se abrazara con el cuello;

73 Estábaselo con mucho sosiego mirando don Quijote,

80 A lo cual don Quijote respondió con mucho entono y gravedad:

\author{
La meiosis es \\ irónica porque don \\ Quijote sí quedó \\ dañado: el vizcaíno \\ le lastimó la oreja.
}

\title{
La pelea es
}

comparable a las de las novelas de caballerías.

\author{
Otra vez, la furia \\ de don Quijote es \\ desproporcionada \\ para el contexto. \\ No quiere decir \\ que don Quijote no \\ estuviera enojado.
}

Los combatientes
están furiosos
y don Quijote
hiere gravemente
al vizcaíno:
nuevamente,
lo insólito de la
pelea hace que
la furia parezca
desproporcionada.

El enoijo de don Quijote es comparable al de los protagonistas de las novelas de caballerías.

\section{Don Quijote y el vizcaíno son dos caballeros comparables a los de los libros de caballería. No se quiere decir que don Quijote y el vizcaíno no peleaban con fiereza, sino que esa fiereza es patética y digna de risa, al mismo tiempo.}

\section{Parece que el sosiego se contradice con la tensión de la escena.}

Otra vez, parece que el tono grave se contradice con la tensión de la escena.

\section{Don Quijote es comparable a los caballeros andantes de las novelas.}

Don Quijote es comparable a los caballeros andantes de las novelas. 
TABLA 2

Enunciados irónicos en los elogios retóricos

\begin{tabular}{|c|c|c|c|}
\hline & Expresión literal & Cancelación & Enunciado reprobad \\
\hline 8 & $\begin{array}{l}\text { echaba la culpa a la } \\
\text { malignidad del tiempo, } \\
\text { devorador y consumidor } \\
\text { de todas las cosas, el } \\
\text { cual, o la tenía oculta o } \\
\text { consumida. }\end{array}$ & $\begin{array}{l}\text { Aquí el autor juega } \\
\text { con el discurso de las } \\
\text { frases hechas. }\end{array}$ & $\begin{array}{l}\text { Las frases hechas } \\
\text { (como la referida } \\
\text { al tiempo) son } \\
\text { siempre ingeniosas } \\
\text { o verdaderas. }\end{array}$ \\
\hline 9 & $\begin{array}{l}\text { Por otra parte, me } \\
\text { parecía, pues entre sus } \\
\text { libros se habían hallado } \\
\text { tan modernos como } \\
\text { Desengaños de celos y Ninfas } \\
\text { y pastores de Henares, que } \\
\text { también su historia debía } \\
\text { de ser moderna. }\end{array}$ & $\begin{array}{l}\text { Lo dicho } \\
\text { anteriormente } \\
\text { es falso. Esta } \\
\text { desaprobación de } \\
\text { lo que se ha dicho } \\
\text { también parece } \\
\text { característica de } \\
\text { Cervantes. }\end{array}$ & $\begin{array}{l}\text { La oración } 8 . \\
\text { La historia de } \\
\text { don Quijote no es } \\
\text { antigua y, por ello, } \\
\text { no es propia de un } \\
\text { tiempo heroico. }\end{array}$ \\
\hline 55 & $\begin{array}{l}\text { cosa mal hecha y peor } \\
\text { pensada, habiendo } \\
\text { y debiendo ser los } \\
\text { historiadores puntuales, } \\
\text { verdaderos y no nada } \\
\text { apasionados, y que ni el } \\
\text { interés ni el miedo, el } \\
\text { rancor ni la afición, no les } \\
\text { hagan torcer del camino } \\
\text { de la verdad, cuya madre } \\
\text { es la historia, émula del } \\
\text { tiempo, depósito de las } \\
\text { acciones, testigo de lo } \\
\text { pasado, ejemplo y aviso de } \\
\text { lo presente, advertencia } \\
\text { de lo por venir. }\end{array}$ & $\begin{array}{l}\text { Aquí el autor otra vez } \\
\text { juega con el discurso } \\
\text { de las frases hechas. } \\
\text { Se trata de un elogio } \\
\text { retórico de la historia } \\
\text { que sirve para sugerir } \\
\text { que Benengeli es } \\
\text { mentiroso, que } \\
\text { no siempre los } \\
\text { historiadores son } \\
\text { honestos o que las } \\
\text { novelas de caballería } \\
\text { eran textos para } \\
\text { personas ingenuas o } \\
\text { ignorantes. }\end{array}$ & $\begin{array}{l}\text { Las frases hechas } \\
\text { (como la referida } \\
\text { al tiempo) son } \\
\text { siempre ingeniosas } \\
\text { o verdaderas. }\end{array}$ \\
\hline
\end{tabular}

TABLA 3

Enunciados irónicos sobre la documentación histórica

\begin{tabular}{|c|c|c|c|}
\hline & Expresión literal & Cancelación & $\begin{array}{c}\text { Enunciado } \\
\text { reprobado }\end{array}$ \\
\hline 6 & $\begin{array}{l}\text { no había de ser tan } \\
\text { desdichado tan buen } \\
\text { caballero, que le faltase } \\
\text { a él lo que sobró a Platir } \\
\text { y a otros seméjantes. }\end{array}$ & $\begin{array}{l}\text { Parece difícil que un } \\
\text { caballero tan ridículo } \\
\text { como don Quijote tuviera } \\
\text { un sabio prestigioso que } \\
\text { escribiera su historia. }\end{array}$ & $\begin{array}{l}\text { Don Quijote es } \\
\text { un caballero cuya } \\
\text { gloria se compara } \\
\text { a la de los héroes } \\
\text { de las novelas }\end{array}$ \\
\hline
\end{tabular}


TABLA 3 (continuación)

7 no podía inclinarme a creer que tan gallarda historia hubiese quedado manca y estropeada.

11 Esta imaginación me traía confuso y deseoso de saber real y verdaderamente toda la vida y milagros de nuestro famoso español don Quijote de la Mancha, luz y espajo de la caballería manchega, y el primero que en nuestra edad y en estos tan calamitosos tiempos se puso al trabajo y ejercicio de las andantes armas, y al desfacer agravios, socorrer viudas, amparar doncellas, de aquellas que andaban con sus azotes y palafrenes, y con toda su virginidad a cuestas, de monte en monte $y$ de valle en valle;

12 que si no era que algún follón, o algún villano de hacha y capellina, o algún descomunal gigante las forzaba, doncella hubo en los pasados tiempos que, al cabo de los ochenta años, que en todos ellos no durmió abajo de tejado, y se fue tan entera a la sepultura como la madre que la había parido.
La historia es ridícula.

Don Quijote es un caballero cuya gloria se compara a la de los héroes de las novelas.

La Mancha es una región muy poco literaria como para tener tradición caballeresca.

Don Quijote es el representante más destacado de la caballería manchega.

Don Quijote no tiene el éxito de los caballeros de las novelas.

Don Quijote cumple con los objetivos de los caballeros andantes.

La virginidad parece una carga para ciertas mujeres no del todo honestas.
A todas las mujeres les importa mantener su virginidad.

Los libros de caballerías son ridículos porque sostienen que antes había mujeres que perdían la virginidad porque las forzaban villanos o gigantes.

\author{
Es verdadero \\ que, como \\ cuentan las \\ novelas de \\ caballería, en \\ el pasado había \\ muchas mujeres \\ que morian \\ vírgenes.
}


Tabla 3 (continuación)

13 Digo, pues, que por estos y otros muchos respetos es digno nuestro gallardo don Quijote de continuas y memorables alabanzas,
Don Quijote no es merecedor de alabanzas.
Don Quijote es merecedor de continuas y memorables alabanzas.

(Éste es uno de los casos en los que el enunciado reprobado es el enunciado literal).

Yo (el autor) no soy $\quad$ Yo (el autor) merecedor de elogios por soy merecedor encontrar esta historia. de elogios por encontrar esta historia.

Los árabes son confiables.
22 pues aunque le buscara de otra mejor y más antigua lengua, le hallara.

32 haciéndolo ansí, volviendo de improviso el arábigo en castellano, dijo que decía: Historia de don Quijote de la Mancha, escrita por Cide Hamete Benengeli, historiador arábigo.
En el Alcaná de Toledo había muchos árabes. El enunciado parece desvalorizar el lugar donde se encuentran los manuscritos sobre la vida de don Quijote: su objetivo final es desacreditar el origen del historiador Cide Hamete Benengeli.

En el Alcaná de Toledo también hay muchos judíos (hablantes de “otra mejor y más antigua" lengua).

La historia de don Quijote no tiene como autor un sabio de prestigio sino un "sabio" árabe (lo que para la creencia general hará que la obra resulte menos confiable).
Los:judíos son confiables.

El autor de la historia de don Quijote es un prestigioso historiador. 
TABLA 3 (continuación)

40 Pero yo, por facilitar más el negocio y por no dejar de la mano tan buen hallazgo, le truje a mi casa, donde en poco más de mes y medio la tradujo toda, del mesmo modo que aquí se refiere.

51 Si a ésta se le puede poner alguna objeción cerca de su verdad, no podrá ser otra sino haber sido su historiador arábigo, siendo muy propio de los de aquella nación ser mentirosos;

52 aunque, por ser tan nuestros enemigos, antes se puede entender haber quedado falto en ella que demasiado.

54 pues cuando pudiera y debiera estender la pluma en las alabanzas de tan buen caballero, parece que de industria las pasa en silencio;

57 si algo bueno en ella faltare, para mí tengo que fue por culpa del galgo de su autor, antes que por falta del sujeto.
La obra que tienen ante si los lectores es la versión de un traductor (que, además, sea tal vez poco confiable dada su condición de moro).

La historia de don Quijote no tiene como autor un sabio de prestigio sino un "sabio" árabe (lo que para la creencia general hará que la obra resulte menos confiable).

La historia de don Quijote no tiene como autor un sabio de prestigio sino un "sabio" árabe (lo que para la creencia general hará que la obra resulte menos confiable).

\section{La historia de don} Quijote no tiene como autor un sabio de prestigio sino un "sabio" árabe (lo que para la creencia general hará que la obra resulte menos confiable).

La historia de don Quijote no tiene como autor un sabio de prestigio sino un "galgo" árabe (lo que para la creencia general hará que la obra resulte menos confiable).
La historia de don Quijote proviene de fuentes confiables y prestigiosas.

El autor de la historia de don Quijote es un sabio prestigioso y sincero.

Las mentiras de Benengeli no hacen honor a la buena fama de don Quijote.

Las omisiones de Benengeli no hacen honor a la buena fama de don Quijote.

El autor de la historia de don Quijote es un sabio respetable. 
TABLA 4

Enunciados irónicos sobre Dulcinea

\begin{tabular}{|c|c|c|c|}
\hline & Expresión literal & $\begin{array}{c}\text { Cancelación de la } \\
\text { ironía }\end{array}$ & Enunciado reprobado \\
\hline 29 & $\begin{array}{l}\text { "Esta Dulcinea del } \\
\text { Toboso, tantas veces en } \\
\text { esta historia referida, } \\
\text { dicen que tuvo la mejor } \\
\text { mano para salar puercos } \\
\text { que otra mujer de toda la } \\
\text { Mancha". }\end{array}$ & $\begin{array}{l}\text { Los manuscritos } \\
\text { árabes que lee el } \\
\text { moro traductor no } \\
\text { quieren decir que } \\
\text { Dulcinea fuera mala } \\
\text { para la tarea de salar } \\
\text { puercos. Tampoco } \\
\text { quieren decir que } \\
\text { Dulcinea es una } \\
\text { dama delicada. } \\
\text { Aquí, la intención es } \\
\text { poner en evidencia } \\
\text { que las imágenes } \\
\text { de don Quijote } \\
\text { se contradicen } \\
\text { duramente con } \\
\text { los rasgos de una } \\
\text { aldeana. }\end{array}$ & $\begin{array}{l}\text { Dulcinea es la } \\
\text { dama más hermosa } \\
\text { y delicada que } \\
\text { existe (enunciado } \\
\text { de don Quijote). }\end{array}$ \\
\hline 83 & $\begin{array}{l}\text { y es que este caballero me } \\
\text { ha de prometer ir al lugar } \\
\text { del Toboso y presentarse } \\
\text { de mi parte ante la sin } \\
\text { par doña Dulcinea, para } \\
\text { que haga dél lo que más } \\
\text { fuere de su voluntad. }\end{array}$ & $\begin{array}{l}\text { La chata realidad } \\
\text { provinciana } \\
\text { del Toboso se } \\
\text { contradice con los } \\
\text { sitios idealizados } \\
\text { de las novelas de } \\
\text { caballerías. }\end{array}$ & $\begin{array}{l}\text { Dulcinea, la dama } \\
\text { de don Quijote, } \\
\text { vive en el Toboso. } \\
\text { El Toboso es un } \\
\text { país mágico. }\end{array}$ \\
\hline
\end{tabular}

\section{Conclusiones}

El estudio pragmalingüístico de la ironía en el capítulo 9 del Quijote de 1605 nos permite sugerir estas conclusiones:

1. Las ironías del Quijote son implicaturas de enunciados que desaprueban al menos un enunciado ajeno. Como puede 
advertirse en los ejemplos, la ironía no proviene siempre de que "se quiera decir lo contrario de lo que dice literalmente". El enunciado irónico es ecoico (o polifónico) porque en él resuenan las voces de dos implicaturas: la ironía generada y el enunciado reprobado. Generalmente, el enunciado reprobado es la negación de ironía que se genera.

2. El estudio de la ironía parece relacionarse fuertemente con la explotación de las entradas léxicas y enciclopédicas de los conceptos de los enunciados. En efecto, es el conocimiento del mundo que tiene el lector lo que permite entender que una palabra como gallardo o la condición de árabe de Benengeli funcionan irónicamente. La ironía constituye uno de los recursos comunicativos en los que se dice una cosa y se quiere decirotra. En este sentido, el análisis de la ironía puede hacerse muy favorablemente desde un enfoque pragmalingüístico y cognitivo como el que provee la teoría de la relevancia puesto que se describe cómo se relacionan lo literal y lo figurado. La comprensión de los enunciados irónicos no difiere de la comprensión de otros tipos de enunciados, ni siquiera de aquellos en los que se quiera decir lo mismo que lo que se dice (generándose así una "explicatura"21). La búsqueda de la relevancia lleva a que lectores y oyentes busquen la interpretación que resulte más adecuada.

3. El discurso irónico de Cervantes hace que el lector nunca transite caminos seguros. Las implicaturas generadas por la ironía del Quijote son previsiblemente débiles y no garantizan una interpretación segura como la que pretende dar Homero Simpson a su mujer Marge en el ejemplo [12]. Las contradicciones propuestas por Cervantes son, como vimos, permanentes. Revisemos, nuevamente, el ejemplo [11], lo que el primer narrador dice acerca de la versión histórica de Benengeli:

[11] Si a ésta se le puede poner alguna objeción cerca de su verdad, no podrá ser otra sino haber sido su historiador arábigo, siendo muy propio de los de aquella nación ser mentirosos.

${ }^{21}$ Para Sperber y Wilson, una explicatura es la inferencia que hace el oyen te cuando reconoce que el hablante comunicó lo que dijo de forma literal. La implicatura consistiría en la inferencia del supuesto que comunicó el hablante y que, como su nombre lo indica, expresa algo distinto de la forma literal. Véase supra, nota 13. 
Con esto, el narrador quiere decir que la historia de don Quijote no tiene como autor un sabio de prestigio sino un "sabio" árabe, lo que para la creencia general de la época hará que la obra resulte menos confiable. Así se reprueba (irónicamente) este enunciado: "el autor de la historia de don Quijote es un sabio prestigioso y sincero". Pero luego el narrador dice:

[13] aunque, por ser tan nuestros enemigos, antes se puede entender haber quedado falto en ella que demasiado. $Y$ ansí me parece a mí, pues cuando pudiera y debiera estender la pluma en las alabanzas de tan buen caballero, parece que de industria las pasa en silencio; cosa mal hecha y peor pensada (Quijote, I, cap. 9, p. 104).

Ahora el enunciado que se reprueba es éste: las mentiras de Benengeli no hacen honor a la buena fama de don Quijote. Y el enunciado reprobado se contradice con aquellos que desvalorizaban el supuesto prestigio del héroe manchego. Primero, se dio a entender que don Quijote era ridículo y que no merecía otro historiador que no fuera un "galgo" árabe, pero luego se cuestiona a ese historiador por no alabar al caballero español como se lo merece. Nótese lo difícil e inestable que es la caracterización de la ironía en el Quijote. Los enunciados desaprobados no coinciden completamente entre sí. La obra de Benengeli no es confiable porque su autor es árabe. Pero don Quijote aparece, al mismo tiempo, como personaje ridículo (por haber sido motivo de un sabio árabe) y como personaje digno de reivindicación (porque un árabe miente o retacea datos). De modo similar, el primer narrador juega con el discurso de las frases hechas. Se trata de un elogio retórico de la historia que sirve para sugerir que Benengeli es mentiroso o que no siempre los historiadores son honestos.

[14] cosa mal hecha y peor pensada, habiendo y debiendo ser los historiadores puntuales, verdaderos y no nada apasionados, y que ni el interés ni el miedo, el rancor ni la afición, no les hagan torcer del camino de la verdad, cuya madre es la historia, émula del tiempo, depósito de las acciones, testigo de lo pasado, ejemplo y aviso de lo presente, advertencia de lo por venir (loc. cit.).

El elogio retórico de la Historia no parece inocente. El enunciado que se reprueba es "La Historia es una ciencia desarrolla- 
da por gente honesta". Si lo que escribí en la oración anterior es verdadero -si Cervantes efectivamente es irónico con respecto a los historiadores y no sólo con respecto a los libros de caballerías que se presentaban como versiones históricas verdaderas-, entonces el lector devoto, de Cervantes, tendrá la oportunidad de disentir con el ácido crítico de "Pierre Menard autor del Quijote", quien se niega a reconocer la ironía de Cervantes al tiempo que atribuye a su amigo, Menard, una visión original de la historia, entendida como la interpretación de lo que pudo haber sido ${ }^{22}$.

4. Para terminar con el análisis de las ironías y de las contradicciones intencionales de Cervantes, el relato da a entender que la historia de don Quijote proviene de gente indigna y nada confiable, los árabes (lo son el historiador y su traductor); podría aun provenir de los judíos. No se puede concluir que Cervantes o el Quijote sean "racistas"; el texto simplemente juega con las creencias de la época. Con su origen dudoso y sus derrotas a cuestas, don Quijote termina siendo un personaje admirable. De esa contradicción, imposible de resolver, pero también imposible de pasar por alto, nace tal vez la ironía más sublime de Cervantes.

José María GiL Universidad de Mar del Plata-CONICET

\section{APÉNDICE}

\section{CAPÍTULO 9}

Donde se concluye y da fin a la estupenda batalla que el gallardo vizcaíno y el valiente manchego tuvieron

Dejamos en la primera parte desta historia al valeroso vizcaíno y al famoso don Quijote con las espadas altas y desnudas, en guisa de descargar dos furibundos fendientes, tales, que si en lleno se acertaban, por lo menos se dividirían y fenderían de arriba a abajo y abrirían como una granada y que en aquel punto tan dudoso paró y quedó destroncada tan sabrosa historia, sin que nos diese noticia su autor dónde se podría hallar lo que della faltaba.

${ }^{22}$ Jorge Luis Borges, "Pierre Menard autor del Quijote", en Obras completas (1923-1972), Emecé, Buenos 'Aires, 1974, pp. 444-450. 
Causóme esto mucha pesadumbre porque el gusto de haber leído tan poco se volvía en disgusto, de pensar el mal camino que se ofrecía para hallar lo mucho que, a mi parecer, faltaba de tan sabroso cuento. Parecióme cosa imposible y fuera de toda buena costumbre que a tan buen caballero le hubiese faltado algún sabio que tomara a cargo el escrebir sus nunca vistas hazañas, cosa que no faltó a ninguno de los caballeros andantes,

de los que dicen las gentes

que van a sus aventuras,

porque cada uno dellos tenía uno o dos sabios, como de molde, que no solamente escribían sus hechos, sino que pintaban sus más mínimos pensamientos y niñerías, por más escondidas que fuesen; y no había de ser tan desdichado tan buen caballero, que le faltase a él lo que sobró a Platir y a otros semejantes. Yasí, no podía inclinarme a creer que tan gallarda historia hubiese quedado manca y estropeada, y echaba la culpa a la malignidad del tiempo, devorador y consumidor de todas las cosas, el cual, o la tenía oculta o consumida.

Por otra parte, me parecía que, pues entre sus libros se habían hallado tan modernos como Desengaños de celos y Ninfas y pastores de Henares, que también su historia debía de ser moderna, y que, ya que no estuviese escrita, estaría en la memoria de la gente de su aldea y de las a ella circunvecinas. Esta imaginación me traía confuso y deseoso de saber real y verdaderamente toda la vida y milagros de nuestro famoso español don Quijote de la Mancha, luz y espejo de la caballería manchega, y el primero que en nuestra edad y en estos tan calamitosos tiempos se puso al trabajo y ejercicio de las andantes armas, y al desfacer agravios, socorrer viudas, amparar doncellas, de aquellas que andaban con sus azotes y palafrenes, y con toda su virginidad a cuestas, de monte en monte y de valle en valle; que si no era que algún follón, o algún villano de hacha y capellina, o algún descomunal gigante las forzaba, doncella hubo en los pasados tiempos que, al cabo de los ochenta años, que en todos ellos no durmió abajo de tejado, y se fue tan entera a la sepultura como la madre que la había parido. Digo, pues, que por estos y otros muchos respetos es digno nuestro gallardo don Quijote de continuas y memorables alabanzas, y aun a mí no se me deben negar, por el trabajo y diligencia que puse en buscar el fin desta agradable historia; aunque bien sé que si el cielo, el caso y la fortuna no me ayudan, el mundo quedará fal to y sin el pasatiempo y gusto de que bien casi dos horas podrá tener el que con atención la leyere. Pasó, pues, desta manera:

Estando yo un día en el Alcaná de Toledo, llegó un muchacho a vender unos cartapacios y papeles viejos a un sedero; y como yo soy aficionado a leer, aunque sean los papeles rotos de las calles, llevado desta mi natural inclinación, tomé un cartapacio de los que el muchacho vendía, y vile con caracteres que conocí ser arábigos. Y puesto que aunque los conocía no los sabía leer, anduve mirando si parecía por allí algún morisco aljamiado que los leyese, y no fue muy dificultoso hallar intérprete semejante, pues aunque le buscara de otra mejor y más antigua lengua, le hallara. En fin, la suerte me deparó uno que, diciéndole mi deseo y poniéndole el libro en las manos, le abrió por medio, y leyendo poco en él, se comenzó a reír. 
Preguntéle yo de qué se reía, y respondióme que de una cosa que tenía aquel libro escrita en el margen por anotación. Dijele que me la dijese, y él, sin dejar la risa, dijo:

-Está, como he dicho, aquí en el margen escrito esto: "Esta Dulcinea del Toboso, tantas veces en esta historia referida, dicen que tuvo la mejor mano para salar puercos que otra mujer de toda la Mancha".

Cuando yo oí decir "Dulcinea del Toboso", quedé atónito y suspenso. porque luego se me representó que aquellos cartapacios contenían la historia de don Quijote. Con esta imaginación, le di priesa que leyese el principio, y, haciéndolo ansí, volviendo de improviso el arábigo en castellano, dijo que decía: Historia de don Quijote de la Mancha, escrita por Cide Hamete Benengeli, historiador arábigo. Mucha discreción fue menester para disimular el contento que recebí cuando llegó a mis oídos el título del libro; y, salteándosele al sedero, compré al muchacho todos los papeles y cartapacios por medio real; que si él tuviera discreción y supiera lo que yo los deseaba, bien se pudiera prometer y llevar más de seis reales de la compra. Apartéme luego con el morisco por el claustro de la iglesia mayor, y roguéle me volviese aquellos cartapacios, todos los que trataban de don Quijote, en lengua castellana, sin quitarles ni añadirles nada, ofreciéndole la paga que él quisiese. Contentóse con dos arrobas de pasas y dos fanegas de trigo, y prometió traducirlos bien y fielmente y con mucha brevedad. Pero yo, por facilitar más el negocio y por no déjar de la mano tan buen hallazgo, le truje a mi casa, donde en poco más de mes y medio la tradujo toda, del mesmo modo que aquí se refiere.

Estaba en el primero cartapacio pintada muy al natural la batalla de don Quijote con el vizcaíno, puestos en la mesma postura que la historia cuenta, levantadas las espadas, el uno cubierto de su rodela, el otro de la almohada, y la mula del vizcaîno tan al vivo, que estaba mostrando ser de alquiler a tiro de ballesta. Tenía a los pies escrito el vizcaíno un título que decía: Don Sancho de Azpetia, que, sin duda, debía ser su nombre, y a los pies de Rocinante estaba otro que decía: Don Quijote. Estaba Rocinante maravillosamente pintado, tan largo y tendido, tan atenuado y flaco, con tanto espinazo, tan hético confirmado, que mostraba bien al descubierto con cuánta advertencia y propiedad se le había puesto el nombre de Rocinante. Junto a él estaba Sancho Panza, que tenía del cabestro a su asno, a los pies del cual estaba otro rétulo que decía: Sancho Zancas, y debía ser que tenía, a lo que mostraba la pintura, la barriga grande, el talle corto y las zancas largas, y por esto se le debió poner el nombre de Panza y de Zancas, que con estos dos sobrenombres le llama algunas veces la historia. Otras algunas menudencias había que advertir, pero todas son de poca importancia y que no hacen al caso a la verdadera relación de la historia, que ninguna es mala como sea verdadera.

Si a ésta se le puede poner alguna objeción cerca d $₫$ su verdad, no podrá ser otra sino haber sido su historiador arábigo, siendo muy propio de los de aquella nación ser mentirosos; aunque, por ser tan nuestros enemigos, antes se puede entender haber quedado falto en ella que demasiado. Yansí me parece a mí, pues cuando pudiera y debiera estender la pluma en las alabanzas de tan buen caballero, parece que de industria las pasa en silencio; cosa mal hecha y peor pensada, habiendo y debiendo ser los historiadores puntuales, verdaderos y no nada apasionados, y que ni el interés ni el miedo, el rancor ni la afición, no les hagan torcer del camino de la verdad, cuya madre es la 
historia, émula del tiempo, depósito de las acciones, testigo de lo pasado, ejemplo y aviso de lo presente, advertencia de lo por venir. En ésta sé que hallará todo lo que se acertare a desear en la más apacible; y si algo bueno en ella faltare, para mí tengo que fue por culpa del galgo de su autor, antes que por falta del sujeto. En fin, su segunda parte, siguiendo la traducción, comenzaba desta manera:

Puestas y levantadas en al to las cortadoras espadas de los dos valerosos y enojados combatientes, no parecía sino que estaban amenazando al cielo, a la tierra y al abismo: tal era el denuedo y el continente que tenían. Y el primero que fue a descargar el golpe fue el colérico vizcaíno; el cual fue dado con tanta fuerza y tanta furia que, a no volvérsele la espada en el camino, aquel solo golpe fuera bastante para dar fin a su rigurosa contienda y a todas las aventuras de nuestro caballero; mas la buena suerte, que para mayores cosas le tenía guardado, torció la espada de su contrario, de modo que, aunque le acertó en el hombro izquierdo, no le hizo otro daño que desarmarle todo aquel lado, llevándole, de camino, gran parte de la celada, con la mitad de la oreja; que todo ello con espantosa ruina vino al suelo, dejándole muy maltrecho.

¿Váleme Dios, y quién será aquel que buenamente pueda contar ahora la rabia que entró en el corazón de nuestro manchego, viéndose parar de aquella manera! No se diga más sino que fue de manera, que se alzó de nuevo con los estribos, y apretando más la espada en las dos manos, con tal furia descargó sobre el vizcaíno, acertándole de lleno sobre la almohada y sobre la cabeza, que, sin ser parte tan buena defensa, como si cayera sobre él una montaña, comenzó a echar sangre por las narices y por la boca, y por los oídos, y a dar muestras de caer de la mula abajo, de donde cayera, sin duda, si no se abrazara con el cuello; pero, con todo eso, sacó los pies de los estribos y luego soltó los brazos, y la mula, espantada del terrible golpe, dio a correr por el campo, y a pocos corcovos dio con su dueño en tierra.

Estábaselo con mucho sosiego mirando don Quijote, y como lo vio caer, saltó de su caballo y con mucha ligereza se llegó a él, poniéndole la punta de la espada en los ojos, le dijo que se rendiese; si no, que le cortaría la cabeza. Estaba el vizcaíno tan turbado, que no podía responder palabra; y él lo pasara mal, según estaba ciego don Quijote, si las señoras del coche, que hasta ahora con gran desmayo habían mirado la pendencia, no fueran adonde estaba y le pidieran con mucho encarecimiento les hiciese tan gran merced de y favor de perdonar la vida de aquel su escudero. A lo cual don Quijote respondió con mucho entono y gravedad:

-Por cierto, fermosas señoras, yo soy muy contento de hacer lo que me pedís; mas ha de ser con una condición y concierto, y es que este caballero me ha de prometer ir al lugar del Toboso y presentarse de mi parte ante la sin par doña Dulcinea, para que haga dél lo que más fuere de su voluntad.

Las temerosas y desconsoladas señoras, sin entrar en cuenta de lo que don Quijote pedía, y sin preguntar quién Dulcinea fuese, le prometieron que el escudero haría todo aquello que de su parte le fuese mandado.

-Pues en fe de esa palabra, yo no le haré más daño, puesto que me lo tenía bien merecido. 


\section{DIVISIÓN EN ORACIONESY PROPOSICIONES SUBORDINADAS}

1. Donde se concluye y da fin a la estupenda batalla que el gallardo vizcaíno y el valiente manchego tuvieron

1.1. que el gallardo vizcaíno y el valiente manchego tuvieron

2. Dejamos en la primera parte desta historia al valeroso vizcaíno y al famoso don Quijote con las espadas altas y desnudas, en guisa de descargar dos furibundos fendientes, tales, que si en lleno se acertaban, por lo menos se dividirían y fenderían de arriba a abajo y abrirían como una granada

2.1. descargar dos furibundos fendientes, tales, que si en lleno se acertaban, por lo menos se dividirían y fenderían de arriba a abajo y abrirían como una granada

2.1.1. que si en lleno se acertaban, por lo menos se dividirían y fenderían de arriba a abajo y abrirían como una granada

2.1.1.1. si en lleno se acertaban,

2.1.1.2. por lo menos se dividirían y fenderían de arriba a abajo

2.1.1.3. y abrirían como una granada

y que (conector)

3. en aquel punto tan dudoso paró y quedó destroncada tan sabrosa historia, sin que nos diese noticia su autor dónde se podría hallar lo que della faltaba.

3.1. sin que nos diese noticia su autor dónde se podría hallar lo que della faltaba.

3.1.1. dónde se podría hallar lo que della faltaba.

3.1.1.1. lo que della faltaba.

4. Causóme esto mucha pesadumbre porque el gusto de haber leído tan poco se volvía en disgusto, de pensar el mal camino que se ofrecía para hallar lo mucho que, a mi parecer, faltaba de tan sabroso cuento.

4.1. porque el gusto de haber leído tan poco se volvía en disgusto, de pensar el mal camino que se ofrecía para hallar lo mucho que, a mi parecer, faltaba de tan sabroso cuento.

4.1.1. haber leído tan poco

4.1.2. pensar el mal camino que se ofrecía para hallar lo mucho que, a mi parecer, faltaba de tan sabroso cuento.

4.1.2.1. que se ofrecía para hallar lo mucho que, a mi parecer, faltaba de tan sabroso cuento.

4.1.2.1.1. hallar lo mucho que, a mi parecer, faltaba de tan sabroso cuento.

4.1.2.1.1.1. que, a mi parecer, faltaba de tan sabroso cuento.

5. Parecióme cosa imposible y fuera de toda buena costumbre que a tan buen caballero le hubiese faltado algún sabio que tomara a cargo el escrebir sus nunca vistas hazañas, cosa que no faltó a ninguno de los caballeros andantes, 
de los que dicen las gentes / que van a sus aventuras, porque cada uno dellos tenía uno o dos sabios, como de molde, que no solamente escribían sus hechos, sino que pintaban sus más mínimos pensamientos y niñerías, por más escondidas que fuesen;

5.1. porque cada uno dellos tenía uno o dos sabios, como de molde, que no solamente escribían sus hechos, sino que pintaban sus más mínimos pensamientos y niñerías, por más escondidas que fuesen;

5.1.1. que no solamente escribían sus hechos, sino que pintaban sus más mínimos pensamientos y niñerías, por más escondidas que fuesen;

5.1.2. que no solamente escribían sus hechos, sino que pintaban sus más mínimos pensamientos y niñerías, por más escondidas que fuesen;

5.1.2.1. que fuesen

5.2.1. que a tan buen caballero le hubiese faltado algún sabio que tomara a cargo el escrebir sus nunca vistas hazañas, cosa que no faltó a ninguno de los caballeros andantes, / de los que dicen las gentes / que van a sus aventuras,

5.2.1.1. que tomara a cargo el escrebir sus nunca vistas hazañas, cosa que no faltó a ninguno de los caballeros andantes, / de los que dicen las gentes / que van a sus aventuras,

5.2.1.1.1. escrebir sus nunca vistas hazañas, cosa que no faltó a ninguno de los caballeros andantes, / de los que dicen las gentes / que van a sus aventuras,

5.2.1.1.1.1. que no faltó a ninguno de los caballeros andantes, / de los que dicen las gentes / que van a sus aventuras,

5.2.1.1.1.1.1. de los que dicen las gentes / que van a sus aventuras,

5.2.1.1.1.1.1.1. que van a sus aventuras,

$\mathrm{y}($ conector $)$

6. no había de ser tan desdichado tan buen caballero, que le faltase a él lo que sobró a Platir y a otros semejantes.

6.1. que le faltase a él lo que sobró a Platir y a otros semejantes.

6.1.1. lo que sobró a Platir y a otros semejantes.

\section{Yasí (conector)}

7. no podía inclinarme a creer que tan gallarda historia hubiese quedado manca y estropeada

7.1. creer que tan gallarda historia hubiese quedado manca y estropeada 7.1.1. que tan gallarda historia hubiese quedado manca y estropeada

y (conector)

8. echaba la culpa a la malignidad del tiempo, devorador y consumidor de todas las cosas, el cual, o la tenía oculta o consumida. 
8.1. el cual, o la tenía oculta o consumida.

Por otra parte (conector)

9. me parecía que, pues entre sus libros se habían hallado tan modernos como Desengaños de celos y Ninfas y pastores de Henares, que también su historia debía de ser moderna,

9.1. que, pues entre sus libros se habían hallado tan modernos como Desengaños de celos y Ninfas y pastores de Henares, que también su historia debía de ser moderna,

9.1.1. pues entre sus libros se habían hallado tan modernos como Desengaños de celos y Ninfas y pastores de Henares

y (conector)

10. (me parecía) que, ya que no estuviese escrita, estaría en la memoria de la gente de su aldea y de las a ella circunvecinas.

10.1. que, ya que no estuviese escrita, estaría en la memoria de la gente de su aldea y de las a ella circunvecinas.

10.1.1. ya que no estuviese escrita

(ya que, con valor de concesivo).

11. Esta imaginación me traía confuso y deseoso de saber real y verdaderamente toda la vida y milagros de nuestro famoso español don Quijote de la Mancha, luz y espejo de la caballería manchega, y el primero que en nuestra edad y en estos tan calamitosos tiempos se puso al trabajo y ejercicio de las andantes armas, y al desfacer agravios, socorrer viudas, amparar doncellas, de aquellas que andaban con sus azotes y palafrenes, y con toda su virginidad a cuestas, de monte en monte y de valle en valle;

11.1. que en nuestra edad y en estos tan calamitosos tiempos se puso al trabajo y ejercicio de las andantes armas,

11.2. al desfacer agravios,

11.3. socorrer viudas,

11.4. amparar doncellas, de aquellas que andaban con sus azotes y palafrenes, y con toda su virginidad a cuestas, de monte en monte y de valle en valle;

11.4.1. que andaban con sus azotes y palafrenes, y con toda su virginidad a cuestas, de monte en monte y de valle en valle;

que (conector)

12. si no era que algún follón, o algún villano de hacha y capellina, o algún descomunal gigante las forzaba, doncella hubo en los pasados tiempos que, al cabo de los ochenta años, que en todos ellos no durmió abajo de tejado, y se fue tan entera a la sepultura como la madre que la había parido. 
12.1. si no era que algún follón, o algún villano de hacha y capellina, o algún descomunal gigante las forzaba,

12.1.1. que algún follón, o algún villano de hacha y capellina, o algún descomunal gigante las forzaba,

12.2. que, al cabo de los ochenta años, que en todos ellos no durmió abajo de tejado,

12.3. se fue tan entera a la sepultura como la madre que la había parido.

12.3.1. que la había parido.

13. Digo, pues, que por estos y otros muchos respetos es digno nuestro gallardo don Quijote de continuas y memorables alabanzas,

13.1. por estos y otros muchos respetos es digno nuestro gallardo don Quijote de continuas y memorables alabanzas,

14. aun a mí no se me deben negar, por el trabajo y diligencia que puse en buscar el fin desta agradable historia;

14.1. que puse en buscar el fin desta agradable historia

14.1.1. buscar el fin desta agradable historia

aunque (conector)

15. bien sé que si el cielo, el caso y la fortuna no me ayudan, el mundo quedará falto y sin el pasatiempo y gusto de que bien casi dos horas podrá tener el que con atención la leyere.

15.1. si el cielo, el caso y la fortuna no me ayudan, el mundo quedará falto y sin el pasatiempo y gusto de que bien casi dos horas podrá tener el que con atención la leyere.

15.1.1. si el cielo, el caso y la fortuna no me ayudan,

15.1.2. el mundo quedará falto y sin el pasatiempo y gusto de que bien casi dos horas podrá tener el que con atención la leyere.

15.1.2.1. que bien casi dos horas podrá tener el que con atención la leyere.

15.1.2.1.1. el que con atención la leyere

16. Pasó, pues, desta manera:

17. Estando yo un día en el Alcaná de Toledo, llegó un muchacho a vender unos cartapacios y papeles viejos a un sedero;

17.1. Estando yo un día en el Alcaná de Toledo,

17.2. vender unos cartapacios y papeles viejos a un sedero;

18. y como yo soy aficionado a leer, aunque sean los papeles rotos de las calles, llevado desta mi natural inclinación, tomé un cartapacio de los que el muchacho vendía, 
18.1. como yo soy aficionado a leer, aunque sean los papeles rotos de las calles,

18.1.1. aunque sean los papeles rotos de las calles

18.2. llevado desta mi natural inclinación,

18.3. de los que el muchacho vendía,

19. y vile con caracteres que conocí ser arábigos.

19.1. que conocí ser arábigos

20. Y puesto que aunque los conocía no los sabía leer, anduve mirando si parecía por allí algún morisco aljamiado que los leyese,

20.1. aunque los conocía no los sabía leer

20.1.1 aunque los conocía

20.1.2. no los sabía leer

20.2. anduve mirando si parecía por allí algún morisco aljamiado que los leyese,

20.2.1. si parecía por allí algún morisco aljamiado que los leyese,

20.2.1.1. que los leyese,

$y($ conector $)$

21. no fue muy dificultoso hallar intérprete semejante,

21.1. hallar intérprete semejante,

pues (conector)

22. aunque le buscara de otra mejor y más antigua lengua, le hallara.

22.1 aunque le buscara de otra mejor y más antigua lengua,

22.2. le hallara.

23. En fin, la suerte me deparó uno que, diciéndole mi deseo y poniéndole el libro en las manos, le abrió por medio, y leyendo poco en él, se comenzó a reír.

23.1. que, diciéndole mi deseo y poniéndole el libro en las manos, le abrió por medio,

23.1.1. diciéndole mi deseo

23.1.2. poniéndole el libro en las manos

23.2. y leyendo poco en él, se comenzó a reír.

23.2.1. leyendo poco en él

24. Preguntéle yo de qué se reía,

24.1. de qué se reía 
25. respondióme que de una cosa que tenía aquel libro escrita en el margen por anotación.

25.1. que (se reía) de una cosa que tenía aquel libro escrita en el margen por anotación.

25.1.1. que tenía aquel libro escrita en el margen por anotación.

26. Dijjele que me la dijese,

26.1. que me la dijese,

y

27. él, sin dejar la risa, dijo:

27.1. sin dejar la risa

28. Está, como he dicho, aquí en el margen escrito esto:

28.1. como he dicho

29. "Esta Dulcinea del Toboso, tantas veces en esta historia referida, dicen que tuvo la mejor mano para salar puercos que otra mujer de toda la Mancha".

29.1. Esta Dulcinea del Toboso, tantas veces en esta historia referida, tuvo la mejor mano para salar puercos que otra mujer de toda la Mancha.

30. Cuando yo oí decir "Dulcinea del Toboso", quedé atónito y suspenso, porque luego se me representó que aquellos cartapacios contenían la historia de don Quijote.

30.1. Cuando yo oí decir "Dulcinea del Toboso",

30.2. porque luego se me representó que aquellos cartapacios contenían la historia de don Quijote.

30.2.1. que aquellos cartapacios contenían la historia de don Quijote.

31. Con esta imaginación, le di priesa que leyese el principio,

31.1. que leyese el principio,

$y$,

32. haciéndolo ansí, volviendo de improviso el arábigo en castellano, dijo que decía: Historia de don Quijote de la Mancha, escrita por Cide Hamete Benengeli, historiador arábigo.

32.1. haciéndolo ansí, 
32.2. volviendo de improviso el arábigo en castellano,

32.3. que decía: Historia de don Quijote de la Mancha, escrita por Cide Hamete Benengeli, historiador arábigo.

33. Mucha discreción fue menester para disimular el contento que recebí cuando llegó a mis oídos el título del libro;

33.1. que recebí

33.2. cuando llegó a mis oídos el título del libro;

y,

34. salteándosele al sedero, compré al muchacho todos los papeles y cartapacios por medio real;

34.1. salteándosele al sedero,

que

35. si él tuviera discreción y supiera lo que yo los deseaba, bien se pudiera prometer y llevar más de seis reales de la compra.

35.1. si él tuviera discreción y supiera lo que yo los deseaba,

35.1.1. él tuviera discreción

35.1.1. supiera lo que yo los deseaba,

36. Apartéme luego con el morisco por el claustro de la iglesia mayor,

y

37. roguéle me volviese aquellos cartapacios, todos los que trataban de don Quijote, en lengua castellana, sin quitarles ni añadirles nada, ofreciéndole la paga que él quisiese.

37.1. me volviese aquellos cartapacios, todos los que trataban de don Quijote, en lengua castellana, sin quitarles ni añadirles nada, ofreciéndole la paga que él quisiese.

37.1.1. los que trataban de don Quijote

37.1.2. sin quitarles ni añadirles nada

37.1.3. ofreciéndole la paga que él quisiese.

37.1.3.1. que él quisiese.

38. Contentóse con dos arrobas de pasas y dos fanegas de trigo,

39. prometió traducirlos bien y fielmente y con mucha brevedad.

39.1. traducirlos bien y fielmente y con mucha brevedad. 
40. Pero yo, por facilitar más el negocio y por no dejar de la mano tan buen hallazgo, le truje a mi casa, donde en poco más de mes y medio la tradujo toda, del mesmo modo que aquí se refiere.

40.1. por facilitar más el negocio

40.2. por no dejar de la mano tan buen hallazgo

40.3. donde en poco más de mes y medio la tradujo toda, del mesmo modo que aqui se refiere.

40.3.1. que aquí se refiere.

41. Estaba en el primero cartapacio pintada muy al natural la batalla de don Quijote con el vizcaíno, puestos en la mesma postura que la historia cuenta, levantadas las espadas, el uno cubierto de su rodela, el otro de la almohada, y la mula del vizcaíno tan al vivo, que estaba mostrando ser de alquiler a tiro de ballesta.

41.1. que la historia cuenta

41.2. el uno cubierto de su rodela,

41.3. el otro de la almohada,

41.4. y la mula del vizcaíno tan al vivo, que estaba mostrando ser de alquiler a tiro de ballesta.

41.4.1. estaba mostrando ser de alquiler a tiro de ballesta.

41.4.1.1. ser de alquiler a tiro de ballesta.

42. Tenía a los pies escrito el vizcaíno un título que decía: Don Sancho de Azpetia, que, sin duda, debía ser su nombre,

42.1. que decía: Don Sancho de Azpetia, que, sin duda, debía ser su nombre, 42.1.1. que, sin duda, debía ser su nombre,

43. a los pies de Rocinante estaba otro que decía: Don Quijote.

43.1. que decía: Don Quijote.

44. Estaba Rocinante maravillosamente pintado, tan largo y tendido, tan atenuado y flaco, con tanto espinazo, tan hético confirmado, que mostraba bien al descubierto con cuánta advertencia y propiedad se le había puesto el nombre de Rocinante.

44.1. que mostraba bien al descubierto con cuánta advertencia y propiedad se le había puesto el nombre de Rocinante.

44.1.1. con cuánta advertencia y propiedad se le había puesto el nombre de Rocinante.

45. Junto a él estaba Sancho Panza, que tenía del cabestro a su asno, a los pies del cual estaba otro rétulo que decía: Sancho Zancas,

45.1. que tenía del cabestro a su asno, a los pies del cual estaba otro rétulo que decía: Sancho Zancas, 
45.1.1. a los pies del cual estaba otro rétulo que decía: Sancho Zancas,

46. y debía ser que tenía, a lo que mostraba la pintura, la barriga grande, el talle corto y las zancas largas,

46.1. a lo que mostraba la pintura,

47. y por esto se le debió poner el nombre de Panza y de Zancas, que con estos dos sobrenombres le llama algunas veces la historia.

47.1. que con estos dos sobrenombres le llama algunas veces la historia.

48. Otras algunas menudencias había que advertir,

49. pero todas son de poca importancia

50. y que no hacen al caso a la verdadera relación de la historia, que ninguna es mala como sea verdadera.

50.1. que ninguna es mala como sea verdadera.

51. Si a ésta se le puede poner alguna objeción cerca de su verdad, no podrá ser otra sino haber sido su historiador arábigo, siendo muy propio de los de aquella nación ser mentirosos;

51.1. Si a ésta se le puede poner alguna objeción cerca de su verdad,

51.2. haber sido su historiador arábigo,

51.2.1. siendo muy propio de los de aquella nación ser mentirosos;

52. aunque, por ser tan nuestros enemigos, antes se puede entender haber quedado falto en ella que demasiado.

52.1. aunque, por ser tan nuestros enemigos,

52.2. haber quedado falto en ella que demasiado.

53. Yansí me parece a mí,

54. pues cuando pudiera y debiera estender la pluma en las alabanzas de tan buen caballero, parece que de industria las pasa en silencio;

54.1. cuando pudiera y debiera estender la pluma en las alabanzas de tan buen

54.2. de industria las pasa en silencio;

55. cosa mal hecha y peor pensada, habiendo y debiendo ser los historiadores puntuales, verdaderos y no nada apasionados, y que ni el interés ni el miedo, el rancor ni la afición, no les hagan torcer del camino de la verdad, cuya madre es la historia, émula del tiempo, depósito de las acciones, testigo de lo pasado, ejemplo y aviso de lo presente, advertencia de lo por venir. 
55.1. habiendo y debiendo ser los historiadores puntuales, verdaderos y no nada apasionados,

55.2. ni el interés ni el miedo, el rancor ni la afición, no les hagan torcer del camino de la verdad, cuya madre es la historia, émula del tiempo, depósito de las acciones, testigo de lo pasado, ejemplo y aviso de lo presente, advertencia de lo por venir.

55.2.1. cuya madre es la historia, émula del tiempo, depósito de las acciones, testigo de lo pasado, ejemplo y aviso de lo presente, advertencia de lo por venir.

56. En ésta sé que hallará todo lo que se acertare a desear en la más apacible;

56.1. que hallará todo lo que se acertare a desear en la más apacible;

56.1.1. lo que se acertare a desear en la más apacible;

57. si algo bueno en ella faltare, para mí tengo que fue por culpa del galgo de su autor, antes que por falta del sujeto.

57.1. si algo bueno en ella faltare,

57.2. que fue por culpa del galgo de su autor, antes que por falta del sujeto.

58. En fin, susegundaparte, siguiendola traducción, comenzaba destamanera:

58.1. siguiendo la traducción

59. Puestas y levantadas en alto las cortadoras espadas de los dos valerosos y enojados combatientes, no parecía sino que estaban amenazando al cielo, a la tierra y al abismo:

59.1. Puestas y levantadas en alto las cortadoras espadas de los dos valerosos y enojados combatientes,

59.2. que estaban amenazando al cielo, a la tierra y al abismo:

60. tal era el denuedo y el continente que tenían.

$\mathrm{Y}$

61. el primero que fue a descargar el golpe fue el colérico vizcaíno;

\section{1. que fue a descargar el golpe}

62. el cual fue dado con tanta fuerza y tanta furia que, a no volvérsele la espada en el camino, aquel solo golpe fuera bastante para dar fin a su rigurosa contienda y a todas las aventuras de nuestro caballero;

62.1. a no volvérsele la espada en el camino, aquel solo golpe fuera bastante para dar fin a su rigurosa contienda y a todas las aventuras de nuestro caballero;

62.1.1. a no volvérsele la espada en el camino, 
62.1.2. aquel solo golpe fuera bastante para dar fin a su rigurosa contienda y a todas las aventuras de nuestro caballero;

62.1.2.1. dar fin a su rigurosa contienda y a todas las aventuras de nuestro caballero;

63. mas la buena suerte, que para mayores cosas le tenía guardado, torció la espada de su contrario, de modo que, aunque le acertó en el hombro izquierdo, no le hizo otro daño que desarmarle todo aquel lado, llevándole, de camino, gran parte de la celada, con la mitad de la oreja;

63.1. que para mayores cosas le tenía guardado

64. de modo que, aunque le acertó en el hombro izquierdo, no le hizo otro daño que desarmarle todo aquel lado, llevándole, de camino, gran parte de la celada, con la mitad de la oreja;

64.1. aunque le acertó en el hombro izquierdo,

64.2. desarmarle todo aquel lado,

64.3. llevándole, de camino, gran parte de la celada, con la mitad de la oreja;

65. que todo ello con espantosa ruina vino al suelo, dejándole muy maltrecho.

65.1. dejándole muy maltrecho.

66. Váleme Dios,

67. quién será aquel que buenamente pueda contar ahora la rabia que entró en el corazón de nuestro manchego, viéndose parar de aquella manera

67.1. que buenamente pueda contar ahora la rabia que entró en el corazón de nuestro manchego, viéndose parar de aquella manera

67.1.1. que en tró en el corazón de nuestro manchego, viéndose parar de aquella manera

67.1.1.1. viéndose parar de aquella manera

68. No se diga más sino que fue de manera, que se alzó de nuevo con los estribos, y apretando más la espada en las dos manos, con tal furia descargó sobre el vizcaíno, acertándole de lleno sobre la almohada y sobre la cabeza, que, sin ser parte tan buena defensa, como si cayera sobre él una montaña, comenzó a echar sangre por las narices y por la boca, y por los oídos, y a dar muestras de caer de la mula abajo, de donde cayera, sin duda, si no se abrazara con el cuello;

68.1. que fue de manera,

68.2. que se alzó de nuevo con los estribos

68.3. apretando más la espada en las dos manos, con tal furia descargó sobre el vizcaíno, acertándole de lleno sobre la almohada y sobre la cabeza, que, sin ser parte tan buena defensa, como si cayera sobre 
él una montaña, comenzó a echar sangre por las narices y por la boca, y por los oídos, y a dar muestras de caer de la mula abajo, de donde cayera, sin duda, si no se abrazara con el cuello;

68.3.1. apretando más la espada en las dos manos

68.3.2. acertándole de lleno sobre la almohada y sobre la cabeza, que, sin ser parte tan buena defensa, como si cayera sobre él una montaña, comenzó a echar sangre por las narices y por la boca, y por los oídos, y a dar muestras de caer de la mula abajo, de donde cayera, sin duda, si no se abrazara con el cuello;

68.3.2.1. que, sin ser parte tan buena defensa, como si cayera sobre él una montaña, comenzó a echar sangre por las narices y por la boca, y por los oídos, y a dar muestras de caer de la mula abajo, de donde cayera, sin duda, si no se abrazara con el cuello;

68.3.2.1.1. sin ser parte tan buena defensa

68.3.2.1.2. como si cayera sobre él una montaña, comenzó a echar sangre por las narices y por la boca, y por los oídos, y a dar muestras de caer de la mula abajo, de donde cayera, sin duda, si no se abrazara con el cuello;

68.3.2.1.2.1. comenzó a echar sangre por las narices y por la boca, ypor los 68.3.2.1.2.2. (comenzó a) dar muestras de caer de la mula abajo, de donde cayera, sin duda, si no se abrazara con el cuello;

68.3.2.1.2.2.1. de donde cayera, sin duda, si no se abrazara con el cuello; 68.3.2.1.2.2.1.1. si no se abrazara con el cuello;

68.3.2.1.2. 3. como si cayera sobre él una montaña,

69. pero, con todo eso, sacó los pies de los estribos

70. y luego soltó los brazos,

71. y la mula, espantada del terrible golpe, dio a correr por el campo,

71.1. espantada del terrible golpe,

72. y a pocos corcovos dio con su dueño en tierra.

73. Estábaselo con mucho sosiego mirando don Quijote,

74. y como lo vio caer, saltó de su caballo

74.1. como lo vio caer

75. con mucha ligereza se llegó a él,

76. poniéndole la punta de la espada en los ajos, le dijo que se rendiese;

76.1. poniéndole la punta de la espada en los ojos

76.2. que se rendiese;

77. (le dijo que) si no, que le cortaría la cabeza. 
77.1. si no (se rendía), le cortaría la cabeza.

77.1.1. si no (se rendía)

77.1.2. le cortaría la cabeza.

78. Estaba el vizcaíno tan turbado, que no podía responder palabra;

78.1. que no podía responder palabra;

79. él lo pasara mal, según estaba ciego don Quijote, si las señoras del coche, que hasta ahora con gran desmayo habían mirado la pendencia, no fueran adonde estaba y le pidieran con mucho encarecimiento les hiciese tan gran merced y favor de perdonar la vida de aquel su escudero.

79.1. según estaba ciego don Quijote

79.2. si las señoras del coche, que hasta ahora con gran desmayo habían mirado la pendencia,

79.2.1. que hasta ahora con gran desmayo habían mirado la pendencia,

79.3. no fueran adonde estaba

79.4. le pidieran con mucho encarecimien to les hiciese tan gran merced y favor de perdonar la vida de aquel su escudero.

79.4.1. les hiciese tan gran merced y favor de perdonar la vida de aquel su escudero.

79.4.1.1. perdonar la vida de aquel su escudero.

80. A lo cual don Quijote respondió con mucho entono y gravedad:

81. -Por cierto, fermosas señoras, yo soy muy contento de hacer lo que me pedís;

82. mas ha de ser con una condición y concierto,

83. y es que este caballero me ha de prometer ir al lugar del Toboso y presentarse de mi parte ante la sin par doña Dulcinea, para que haga dél lo que más fuere de su voluntad.

83.1. ir al lugar del Toboso

83.2. presentarse de mi parte ante la sin par doña Dulcinea, para que haga dél lo que más fuere de su voluntad.

83.2.1. para que haga dél lo que más fuere de su voluntad.

83.2.1.1. lo que más fuere de su voluntad.

84. Las temerosas y desconsoladas señoras, sin entrar en cuenta de lo que don Quijote pedía, y sin preguntar quién Dulcinea fuese, le prometieron que el escudero haría todo aquello que de su parte le fuese mandado.

84.1. sin entrar en cuenta de lo que don Quijote pedía,

84.1.1. de lo que don Quijote pedía,

84.2. sin preguntar quién Dulcinea fuese, 
84.2.1. quién Dulcinea fuese,

84.3. que el escudero haría todo aquello que desu parte le fuese mandado. 84.3.1. que de su parte le fuese mandado.

85. -Pues en fe de esa palabra, yo no le haré más daño, puesto que me lo tenía bien merecido.

85.1. puesto que me lo tenía bien merecido. 